\title{
Téoros
}

Revue de recherche en tourisme

\section{Tourisme et religion}

\section{Valérie Théberge}

Volume 16, numéro 2, été 1997

\section{Tourisme et religion}

URI : https://id.erudit.org/iderudit/1074586ar

DOI : https://doi.org/10.7202/1074586ar

Aller au sommaire du numéro

\section{Éditeur(s)}

Université du Québec à Montréal

\section{ISSN}

0712-8657 (imprimé)

1923-2705 (numérique)

Découvrir la revue

Citer ce document

Théberge, V. (1997). Tourisme et religion. Téoros, 16(2), 56-56. https://doi.org/10.7202/1074586ar d'utilisation que vous pouvez consulter en ligne.

https://apropos.erudit.org/fr/usagers/politique-dutilisation/ 


\section{TOURISME ET RELIGION}

Valérie Théberge, bibliothécaire

Centre de documentation touristique UQAM-ACTA

ASSELIN, Jean-Pierre et Lucien GAGNÉ (1984), Sainte-Anne-de-Beaupré : trois cents ans de pelerinage, Sainte-Anne-de-Beaupré,

Basilique Sainte-Anne-de-Beaupré.

BAILLARGEON, Samuel (1991),

Rapport sur les activités pastorales au Sanctuaire de Sainte-Anne-de-Beaupré pour la saison 1991.

Sainte-Anne-de-Beaupré,

Sanctuaire de Sainte-Anne-de-Beaupré.

BELLEFLEUR, Michel (1986),

L'Église et le loisir au Québec: avant la révolution tranquille, Sillery,

Presses de l'Université du Québec.

BUREAU, Claude et al (1987),

Sur les chemins de Dieu: un carnet pour le tourisme religieux en terre québécoise, Sillery, Vie Litturgique.

BYWATER, Marion (1994),

- Religious travel in Europe :.

Travel \& Tourism Analyst, no 2, p. 39-52.

CHOUINARD, Gaétan, (1977),

Les églises et le trésor

de Berthierville, Québec,

Ministère des Affaires culturelles.

CHOUINARD, Gaétan (1978),

Les églises et le trésor de Saint-Pierre

de la Rivière-du-Sud, Québec.

Ministère des Affaires culturelles.

CHOUINARD, Gaétan (1978),

Les monuments historiques

de Laterrière, Québec,

Ministère des Affaires culturelles.

Communauté urbaine de Montréal (1981), Répertoire d'architecture traditionnelle sur le territoire de la Communauté urbaine de Montréal : architecture religieuse, 1 : les églises, Montréal,

Communauté urbaine de Montréal.

CROTEAU, André (1996),

Les belles églises du Québec :

Québec et la Vallée du Saint-Laurent.

Saint-Laurent, Éditions du Trécarré.
GAGNÉ, Lucien et Jean-Pierre ASSELIN (1984), Sainte-Anne-de-Beaupré : trois cents ans de pelerinage, Sainte-Anne-de-Beaupré,

Santuaire de Sainte-Anne-de-Beaupré.

GAGNON, Patrice (1987), Les églises de Charlevoix : un patrimoine à découvrir, Pointe-au-Pic, Conseil régional de pastorale de Charlevoix.

GAUTHIER, Raymonde (1974), Les tabernacles andiens du Québec des XVIr, XVIIr et XIX' siècles, Québec. Ministère des Affaires culturelles.

LAPIERRE, Denis (1984),

Tourisme religieux : support à

la mise en marché de l'offre, Québec, Ministère du Tourisme.

Ministère des Affaires culturelles (1979), La chapelle des Cuthbert :

Berthierville, Québec,

Ministère des Affaires culturelles.

Ministère du Tourisme, de la Chasse et de la Pêche, Églises et sanctuaires du Québec, Québec, Ministère du Tourisme, de la Chasse et de la Pêche.

MURPHY, Achille et al (1977), Les églises du Québec (1600-1850), Québecc, Éditeur Officiel du Québec, Montréal, Fides.

NOPPEN, Luc (1972), Les églises de Charlesbourg et l'architecture religieuse du Québec, Québec, Ministère des Affaires culturelles.

Office des Congrès et du Tourisme du Grand Montréal (1995), Etude sur le potentiel touristique du patrimoine religieux montrealais : rapport final, Montréal, Office des Congrès et du Tourisme du Grand Montréal.
Office des Congrès et du Tourisme du Grand Montréal (1995), Fiches techniques sur les principaux éléments du patrimoine religieux montréalais, Montréal, Office des Congrès et du Tourisme du Grand Montréal.

PORTER, John R. et Léopold DÉSY (1973). Calvaires et croix de chemins du Québec, Québec, Ministère du Tourisme, de la Chasse et de la Pêche.

Ministère de l'Industrie,

du Commerce et du Tourisme, Québec : eglises et sanctuaires, Québec.

ROY, Guy-André (1982),

Le patrimoine religieux de l'lle d'Orléans, Québec;

Ministère des Affaires culturelles.

Société historique Pierre-de-Saurel (1991), Le patrimoine religieux, Sorel, Société historique Pierre-de-Saurel.

STIRLING, J, Craig (1985), Ozias LEDUC et la décoration intérieure de l'église de Saint-Hilaire, Québec. Ministère des Affaires culturelles.

Tourisme et Congrès de Beauce et Corporation de la conservation du patrimoine de St-Simon-les-Mines, Eglise St-Paul-de-Cumberland; étude de marché et de faisabilité. phase 1, St-Georges,

Tourisme et Congrès de Beauce.

(1993), Tourisme religieux, Cahier Espaces, 30, mars.

André Hut, auteur d'un article dans ce numéro et correspondant en Belgique pour Téoros, coordonne le périodique trimestriel PATREL, qui traite d'accueil, d'animation et de formation en patrimoine religieux. Dans le numéro de juin 1997, l'auteur nous parle d'un guide été 1997 en patrimoine religieux pour la Belgique, la France et le Luxembourg. 